e-ISSN 1980-5918

Fisioter. Mov., Curitiba, v. 30, n. 4, p. 671-680, Oct./Dec. 2017

Licenciado sob uma Licença Creative Commons

DOI: http://dx.doi.org/10.1590/1980-5918.030.004.A002

\title{
Effect of high- and low- frequency transcutaneous electrical nerve stimulation (TENS) on angiogenesis and wound contraction in acute excisional wounds in rat skin
}

\author{
Efeito da estimulação elétrica nervosa transcutânea \\ (TENS) de alta e de baixa frequências na angiogênese e na \\ contração da ferida excisional aguda em pele de ratos
}

\author{
Aline Fernanda Perez Machado ${ }^{[a, b, c]}$, Fabio Leite Silva ${ }^{[d]}$, Marco Aurélio Invaldi Neves ${ }^{[c]}$, \\ Fábio Luis Nonato ${ }^{[\mathrm{e}]}$, Pascale Mutti Tacani ${ }^{[\mathrm{a}]}$, Richard Eloin Liebano ${ }^{[\mathrm{f}]^{*}}$
}

[a] Universidade Cidade de São Paulo (UNICID), São Paulo, SP, Brazil

[b] Universidade Paulista (UNIP), São Paulo, SP, Brazil

[c] Universidade Federal de São Paulo (UNIFESP), São Paulo, SP, Brazil

[d] Universidade Federal de São Paulo (UNIFESP), Santos, SP, Brazil

[e] Universidade de Mogi da Cruzes (UMC), Mogi das Cruzes, SP, Brazil

[f] Universidade Federal de São Carlos (UFSCAR), São Carlos, SP, Brazil

\begin{abstract}
Introduction: Transcutaneous electrical nerve stimulation (TENS) can alter the local temperature, increase skin blood flow and induce the release of vasodilator neuropeptides and growth factors. These changes may be related to the effects of TENS on the tissue repair process. Objective: To assess the effect of high- and low-frequency TENS on angiogenesis and the contraction of acute excisional wounds in rat skin. Methods: Fifty-four young adult male EPM1-Wistar rats were used in the study. An excisional wound was performed on the back of each animal using an $8 \mathrm{~mm}$ punch. The animals were randomly assigned to three groups: the
\end{abstract}

\footnotetext{
AFPM: MS, e-mail: lifpm@yahoo.com.br FLS: Master Student, e-mail: fabiolfisio@hotmail.com MAIN: MS, e-mail: marcoain@gmail.com FLN: BS, e-mail: fabio.nonato@terra.com.br PMT: MS, e-mail: pascale.tacani@hotmail.com REL: PhD, e-mail: liebano@gmail.com
} 
High-frequency Group (HG: $80 \mathrm{~Hz}$ ), Low-frequency Group (LG: $5 \mathrm{~Hz}$ ), and Sham Group (SG: TENS turned off). TENS was delivered on three days consecutives. Pulse duration and current intensity were $200 \mu$ s and $15 \mathrm{~mA}$. The length of each TENS session was 60 minutes. Microscopic and macroscopic assessments were performed on 3, 7 and 14 postoperative (PO) days. Hematoxylin-eosin staining was utilized to quantify the neoformed blood vessels. Photographs were taken to determine the percentage of wound contraction. After assessment, the animals were painlessly sacrificed. Results: There were increases in angiogenesis in the HG on the 3 PO day, and in the LG on the 14 PO day. No significant differences in wound contraction were found between the groups on the different PO days. Conclusion: High frequency TENS improved angiogenesis, and neither frequency of TENS had any influence on the contraction of acute excisional wounds in rat skin.

Keywords: Transcutaneous Electric Nerve Stimulation. Wound Healing. Blood Vessels. Rats. Skin.

\section{Resumo}

Introdução: A TENS pode promover alteração da temperatura local, aumento do fluxo sanguíneo cutâneo, liberação de neuropeptídeos vasodilatadores e de fatores de crescimento. Tais eventos podem estar relacionados aos efeitos da TENS no processo de reparo tecidual. Objetivo: Avaliar o efeito da TENS de alta e de baixa frequências na angiogênese e na contração da ferida excisional aguda em pele de ratos. Materiais e Métodos: Foram utilizados 54 ratos (Wistar-EPM1), machos e adultos jovens. Realizou-se uma ferida excisional na região dorsal do animal com um punch medindo 8 milímetros. Os animais foram randomizados em três grupos: Grupo Alta frequência (HG:80 Hz), Grupo Baixa frequência (LG:5 Hz) e Grupo Simulado (SG, TENS desligada). A TENS foi aplicada por 3 dias consecutivos. A duração do pulso e intensidade da corrente foram 200 us e 15 mA. O tempo de cada aplicação foi de 60 minutos. As análises microscópicas e macroscópicas foram feitas nos POI, 3, 7 e 14 dias de pós-operatório (PO). Utilizou-se a hematoxilina-eosina para quantificação dos vasos neoformados. Foram feitas imagens fotográficas para determinação da porcentagem de contração da ferida. Após as avaliações, os animais foram sacrificados. Resultados: Observou-se aumento na quantidade de vasos sanguíneos no HG, aos 3 dias de PO; e no LG, aos 14 dias de PO. Não houve alterações na contração da ferida entre os grupos. Conclusão: A TENS de alta frequência estimulou a angiogênese e ambas as frequências não influenciaram na contração da ferida excisional aguda em pele de ratos.

Palavras-chave: Estimulação Elétrica Nervosa Transcutânea. Cicatrização de Feridas. Vasos Sanguíneos. Ratos. Pele.

\section{Introduction}

Transcutaneous Electrical Nerve Stimulation (TENS) consists of the generic application of pulsed electrical currents, transmitted by electrodes through the intact surface of the skin to stimulate the peripheral nerves, producing various physiological effects. It is a non-pharmacological, non-invasive, low-cost and easy-to-use therapeutic resource, widely used in clinical practice to promote analgesia $(1-4)$. However, some authors have observed that TENS also promotes alterations in skin temperature (5 - 7), increases in local blood flow (7 -9) and the release of vasodilator neuropeptides $(10-12)$ and growth factors (13). These events may be related to the positive effects of TENS on wound healing $(13-24)$ and on the feasibility of skin flaps $(12,24-26)$.

The process of wound healing begins immediately after the injury. The tissue repair of an acute wound can be negatively influenced by changes that can extend the tissue damage and prolong the cicatrization process, causing the wound to become chronic (27 - 29). Among the phases of the healing process, it is considered that the most important phenomena for the complete closure of the wound, angiogenesis, occur in the proliferative phase, which provides means for 
the formation of granulation tissue, and wound contraction initiated by myofibroblasts (27).

The existing scientific basis regarding the use of TENS in wound healing is more evident for chronic wounds initiated or aggravated by diseases such as diabetes (15), leprosy (16), peripheral arterial insufficiency $(6,22)$, chronic venous insufficiency $(19-21)$ and in pressure ulcers in patients with spinal cord injuries $(17,18)$. Considering acute wounds, animal studies have demonstrated that low-frequency TENS optimized the healing of burn lesions in elderly rats (10), improved healing by increasing growth factors in the dermis and epidermis (13) and reduced proinflammatory cytokines in the dermis by inhibiting the inflammatory phase, promoting a decrease in the duration of the cicatrization process (23).

Many studies have observed complete healing of acute and chronic wounds using high and low frequency TENS separately (15 - 23). However, to date, no study has compared the effect of both frequencies of TENS on the healing of acute and chronic wounds. Thus, due to the lack of scientific evidence regarding the effects of the different frequencies of TENS, it is considered necessary to carry out studies to observe the effects on the process of acute wound healing. Therefore, the aim of this study was to evaluate the effect of Transcutaneous Electrical Nerve Stimulation of high and low frequencies on angiogenesis and contraction of the acute excisional wound in rats skin.

\section{Methods}

Study design

This was an experimental, randomized, controlled, blind study. The sample consisted of 54 male, young adult rats (Rattus norvegicus albinus) of the WistarEPM 1 strain, with a mean age of 45 days and weighing between 250 and 350 grams ( $\mathrm{g}$ ). The study began after approval from the Research Ethics Committee of the Federal University of São Paulo (UNIFESP), authorization number 1491/10.

The animals were housed in individual polypropylene cages with free access to water and feed, in a controlled environment according to the standards of the Brazilian College of Animal Experimentation (COBEA).
Sample

The number of animals required was determined by the sample calculation with a mean difference of $0.3 \mathrm{~mm}^{2}( \pm 0.1)$ expected, based on the study of Garros et al. (28). The statistical significance index was $5 \%$ and the power of the sample $80 \%$, with 4 animals in each subgroup, considered the minimum number for statistical representativeness. However, considering the possibility of some loss, two animals were added per subgroup, totaling 6 rats, to avoid possible variables that could interfere with the statistical power.

The animals were randomly assigned (www.randomization.com) into three groups: High Frequency Group (HG/n=18), Low Frequency Group (LG/n = 18) and Sham Group (SG/n = 18), each group was divided into three subgroups $(\mathrm{n}=6)$ according to the postoperative (PO) days: 3, 7 and 14 days. Blinding of the allocation was maintained using opaque and sealed envelopes.

The HG and LG were subjected to the application of the conventional mode of TENS, with Pulse (T) duration of 200 microseconds ( $\mu \mathrm{s})$. The amplitude (I) was 15 milliamperes $(\mathrm{mA})$, as this value demonstrated a smaller area of necrosis in the skin flap $(8,24-26)$ and was used in the first $15 \mathrm{~min}$ in the study of Cosmo et al. (9). The application time was 60 minutes ( $\mathrm{min}$ ), as proposed by Cosmo et al. (9) and in the experimental studies of skin flaps $(24-26)$, for 3 consecutive days, according to Medrado et al. (30). The frequency (f) determined for the HG was 80 Hertz $(\mathrm{Hz})$ and $5 \mathrm{~Hz}$ for the $\mathrm{LG}$. The $\mathrm{SG}$ was subjected to the application of the TENS switched off.

At the end of each procedure, 5 milligrams per kilogram $(\mathrm{mg} / \mathrm{kg})$ body weight of $12 \mathrm{mg}$ tramadol hydrochloride (Dorless $\mathrm{V}^{\circledR}$ ) was administered orally to each animal.

\section{Operative technique}

The animals were anesthetized with 0.2 milliliters $(\mathrm{ml})$ of ketamine hydrochloride $10 \%$ (Ketamine Agener ${ }^{\circledR}$ ) associated with $0.1 \mathrm{ml}$ of xylazine hydrochloride (Calmium ${ }^{\circledR}$, Xylazine $2 \%$ ), intramuscularly in the right gastrocnemius muscle. With the animal anesthetized, epilation was performed by manual traction of dorsal region hair in an area of $6 \mathrm{~cm}$ (cranial-caudal) length by $5 \mathrm{~cm}$ (lateral-lateral) width, centralized in the median dorsal line, totaling an area of $30 \mathrm{~cm}^{2}$. 
To make the wound, a sterile metal punch (Pet Medical $^{\circledR}$ ), 8mm in diameter and depth, was used, which included epidermis, dermis and fleshy pannicus until the fascia superficialis. The surgical wounds did not receive any type of covering and/or dressing during the entire period of the experiment.

\section{Equipment}

The equipment used in this experiment was the pulsed, biphasic, rectangular and symmetric current TENS, Orion Tens ${ }^{\circledR}$ brand [Orion Apparelhos para Fisioterapia LTDA; serial number 00849, Campinas, São Paulo, Brazil], with digital display. The electrical stimulator was measured by an engineer and calibrated with a professional digital oscilloscope, Minipa Mo-2050 (50MHz) brand, prior to the beginning of the experiment, at the Electrical Engineering Laboratory of Universidade Paulista (UNIP). For each pulse of the device, peak-to-peak voltage was measured through a 1 kilo-ohm $(\mathrm{k} \Omega)$ resistor to calculate the amplitude of the current in $\mathrm{mA}$.

The application of the TENS was initiated immediately after the operative procedure and on the subsequent two days. All sessions were held at the same time of day.

The TENS emission was made by an outlet channel with two carbon-silicon electrodes, measuring $4.2 \mathrm{~cm}$ in length and $1.5 \mathrm{~cm}$ in width $(24-26)$, positioned $1 \mathrm{~cm}$ from the upper and lower margins of the excisional wound, containing coupling gel (Carbogel ${ }^{\circledR}$ ) and attached with strips of adhesive tape (Figure 1). The total area of each electrode was $6.3 \mathrm{~cm}^{2}$ and the current density was $2.38 \mathrm{~mA} / \mathrm{cm}^{2}$.

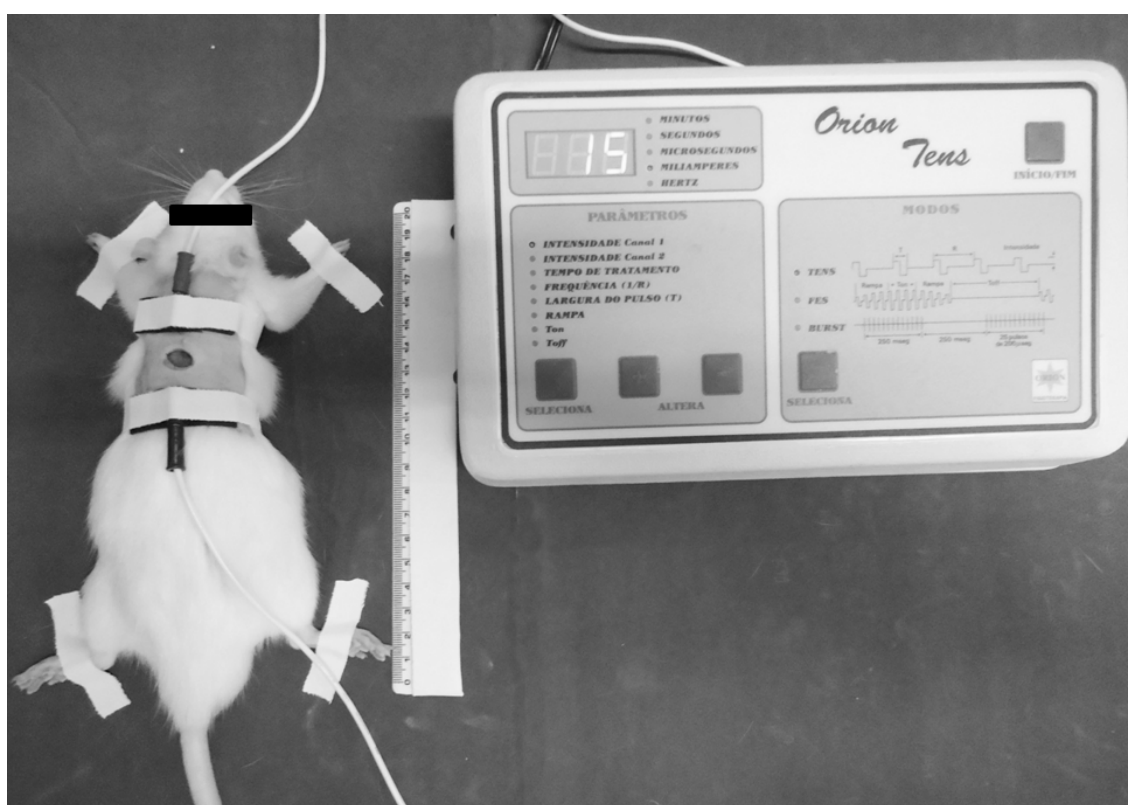

Figure 1 - Application of the TENS demonstrating the positioning and fixation of the electrodes on the skin surface of the animal.

Microscopic analysis

With the animals anesthetized, a skin sample was collected from the dorsal region corresponding to the wound area, having a standardization of $2 \mathrm{~mm}$ in relation to the upper and lower margins and $5 \mathrm{~mm}$ from the lateral margins of the wound, totalizing a variable area in accordance with the PO day according to the subgroup on the respective days of sacrifice.
The samples were fixed in $10 \%$ formalin and sent for analysis. The slides were dewaxed in xylol, hydrated in decreasing alcohol baths until deionized water, stained with Mayer's Hematoxylin, followed by Eosin-Floxin staining. They were then mounted and analyzed by an experienced evaluator (pathologist linked to the Federal University of São Paulo), who had no relation to the present study and did not know which group the slides belonged to. 
Hematoxylin Eosin (HE) was used as the form for the measurement of scar tissue angiogenesis by the quantification of neoformed vessels, identified by the presence of endothelial cells more voluminous in relation to the other vessels.

The analysis of the slides was performed in every area of the wound. Because the tissue sample had a variable size depending on the scar area, the size of the lesion was conditioned to the postoperative day (3, 7 and 14 days, subgroups), with the samples of the 3rd postoperative day being larger when compared to those of the $14^{\text {th }}$ postoperative day.

The images analyzed were obtained using a 100x magnification (10x objective) CoolSNAP-Procf photographic camera (Media Cybernetics Inc., Silver Spring, Maryland, USA) attached to a Nikon Eclipse-E800 microscope. Afterwards, the cicatrization area and the number of neoformed vessels were quantified with the aid of the Image-ProPlus computerized image system, version 4.5 (Media Cybernetics Inc, Silver Spring, Maryland, USA). Then, the wound areas and blood vessels were submitted to a final summation per slide considering the entire extent of the wound. Thus, the number of vessels per $\mu^{2}$ of scar tissue was obtained, and finally the mean number of neoformed vessels by subgroups was calculated.

Photographic evaluation

Photographic images were made to obtain the wound area and for application in the percentage (\%) of wound contraction formula, in the PO interval, 3,7 and 14 PO days, prior to the painless sacrifice of the animals. The photographic images were made using a Sony ${ }^{\circledR}$ (Brazil) Cyber-Shot digital camera, with 14.1 mega pixels resolution. The standardization of the images followed specifications to guarantee the obtained results. The digital camera was placed on a tripod that maintained a standard distance of $20 \mathrm{~cm}$ from the wound, with the animal positioned in a ventral decubitus position, with the front and back paws extended, with an infinite sky blue background (31).

In order to evaluate the therapeutic results of the TENS, the wound area variations were calculated, measured quantitatively on the different days of analysis (32), using the Image J, version 1.44, software (Research Services Branch, US National Institutes of Health, Bethesda, MD, USA). This analysis was performed with the images organized in chronological order and was carried out by an experienced evaluator who did not know which group the animals belonged to. From the wound area values it was possible to calculate the percentage (\%) of contraction of the wound, in which the respective values were inserted into the following formula (33):

$$
\begin{gathered}
\% \text { of wound contraction }= \\
\frac{\text { (initial area - area of the day of analysis })}{\text { initial area }} \times 100
\end{gathered}
$$

According to the items in this formula, the "initial area" in the PO interval corresponded to the area obtained after the operative procedure, calculated from the formula: Area $=\pi \cdot R^{2}$, where $\pi=3.14$ and $R=0.8$, equivalent to the size of the punch used to perform the wound; Thus the value of "initial area" was 0.5024 . The "area of the day of analysis" corresponded to the area of the lesion prior to euthanasia obtained through the analysis with the Image J. software.

The animals were then submitted to euthanasia by intraperitoneal anesthetic overdose, with $500 \mathrm{mg} /$ $\mathrm{kg}$ of ketamine hydrochloride at 10\% (Ketamine Agener $^{\circledR}$ ) being administered with $250 \mathrm{mg} / \mathrm{kg}$ of $\mathrm{xy}-$ lazine hydrochloride $\left(\right.$ Calmium $^{\circledR}$, Xylazine at $\left.2 \%\right)$, Followed by the section of the great cervical vessels.

Statistical analysis

Data were analyzed using the GraphPad Prism ${ }^{\circledR}$ 6.0 for Windows software. To check whether the data presented normal distribution the Shapiro-Wilk test was used. For the evaluation of the angiogenesis and percentage of wound contraction, the Analysis of variance (ANOVA) was used and, if necessary, Tukey's post hoc test. The significance level adopted for the statistical tests was $5 \%(p<0.05)$ and the values were presented as mean and standard deviation $(S D)$. Sample size calculation was performed using the Minitab 15 software.

\section{Results}

Regarding angiogenesis, there were significant changes in the 3 and 14 PO days. At 3 PO days there was an increase in the amount of blood vessels in the HG when compared to the LG and SG $(p<0.0001)$. At 14 PO days, the LG showed a greater amount of 
blood vessels in relation to the HG and SG ( $p=0.0004)$ (Table 1) (Figure 2).

Table 1 - Mean, standard deviation and significance level ( $p$ value) of the angiogenesis of the HG, LG and SG at 3,7 and $14 \mathrm{PO}$ days

\begin{tabular}{lcccc}
\hline \multirow{2}{*}{ PO Days } & Groups & \multicolumn{3}{c}{ Angiogenesis } \\
\cline { 3 - 5 } & & Mean & SD & P value \\
\hline \multirow{3}{*}{3} & HG & $45.50^{\dagger}$ & 5.90 & \\
& LG & 23.57 & 5.03 & $<0.0001^{*}$ \\
& SG & 27.07 & 6.21 & \\
7 & HG & 61.20 & 15.43 & \\
& LG & 48.45 & 8.48 & 0.3809 \\
& SG & 43.53 & 4.15 & \\
\hline \multirow{3}{*}{14} & HG & 23.11 & 3.97 & \\
& LG & $58.64^{\ddagger}$ & 17.29 & $0.0004^{*}$ \\
& SG & 25.51 & 8.39 & \\
\hline
\end{tabular}

Note: ANOVA, Tukey's post hoc. $\mathrm{PO}=$ Postoperative. $\mathrm{HG}=$ High Frequency Group. $L G=$ Low Frequency Group. $S G=$ Simulated Group. $\mathrm{SD}=$ standard deviation. $\mathrm{P}$ value $=$ level of significance. ${ }^{*}=$ statistically significant. $\dagger=$ significant difference of $H G$ from $L G$ and $S G$. $\neq=$ significant difference of $L G$ from $H G$ and $S G$.
Regarding the percentage of wound contraction, there were no significant alterations in the $\mathrm{HG}, \mathrm{LG}$ and SG on the different PO days: $3(p=0.0764), 7$ $(p=0.8449)$ and $14(p=0.2707)$ (Table 2) (Figure 3).

Table 2 - Mean, standard deviation and significance level ( $p$ value) of the wound contraction of the $\mathrm{HG}, \mathrm{LG}$ and $\mathrm{SG}$ at 3,7 and $14 \mathrm{PO}$ days

\begin{tabular}{lcccc}
\hline \multirow{2}{*}{ PO Days } & \multirow{2}{*}{ Groups } & \multicolumn{3}{c}{ Wound contraction (\%) } \\
\cline { 3 - 5 } & & Mean & SD & P value \\
\hline \multirow{3}{*}{3} & HG & 19.32 & 18.07 & \\
& LG & -4.03 & 20.29 & 0.0764 \\
& SG & 20.68 & 19.86 & \\
7 & HG & 48.58 & 21.86 & \\
& LG & 47.35 & 20.29 & 0.8449 \\
& SG & 53.42 & 13.76 & \\
\hline \multirow{3}{*}{14} & HG & 97.81 & 3.25 & \\
& LG & 99.67 & 0.46 & 0.2707 \\
& SG & 99.23 & 1.05 & \\
\hline
\end{tabular}

Note: ANOVA. $H G=$ High Frequency Group; $L G=$ Low Frequency Group; $\mathrm{SG}=$ Simulated Group; $\mathrm{SD}=$ standard deviation; $\mathrm{P}$ value $=$ level of significance.
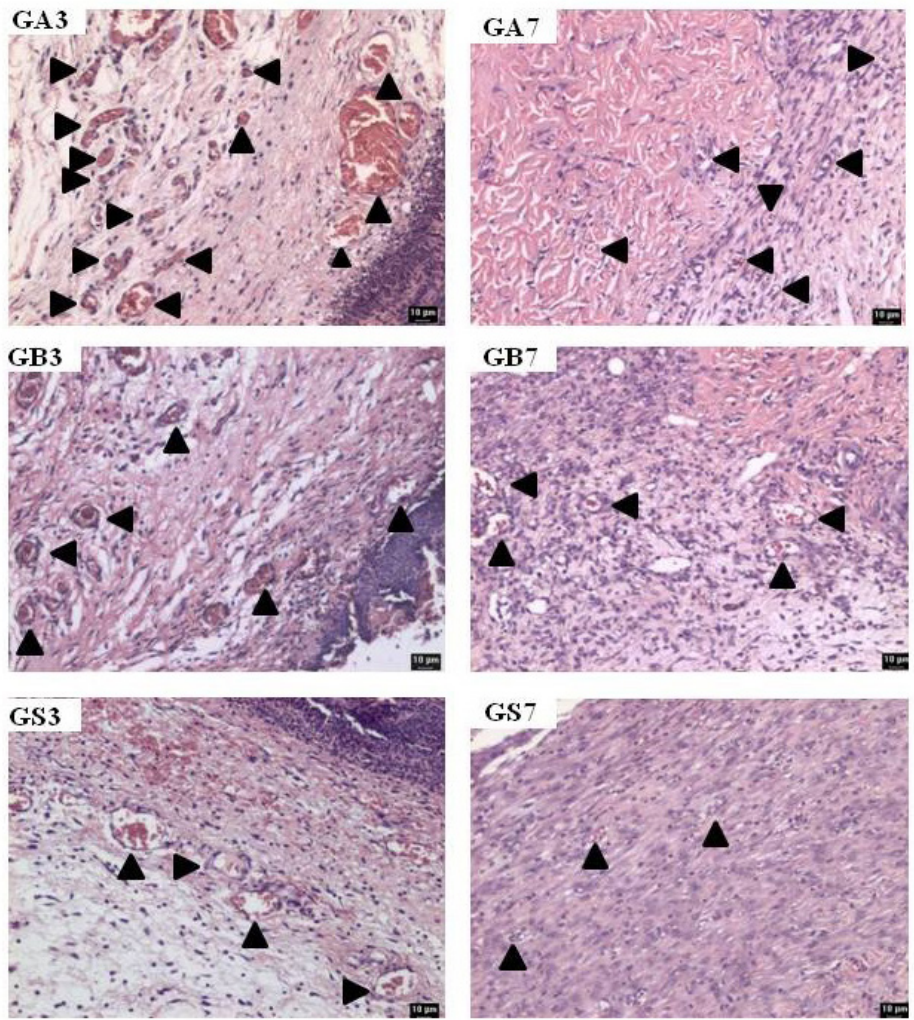
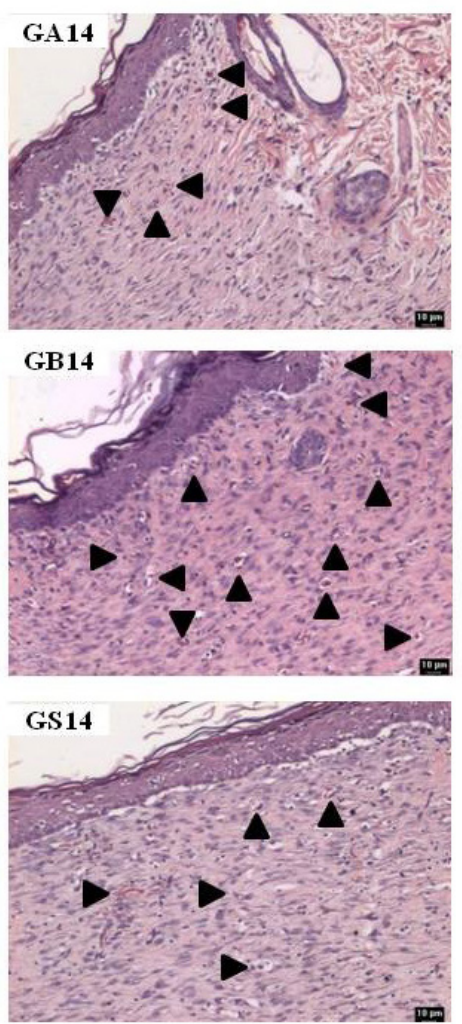

Figure 2 - Angiogenesis in the HG, LG and SG on the 3, 7 and 14 PO days (neoformed vessels shown by the arrows). Note: $\mathrm{HG}=$ High Frequency Group. $\mathrm{LG}=$ Low Frequency Group. SG = Simulated Group. PO = Postoperative. 
GA3

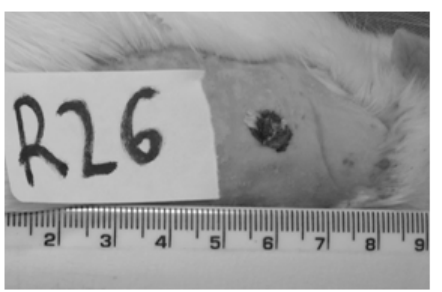

GA 7

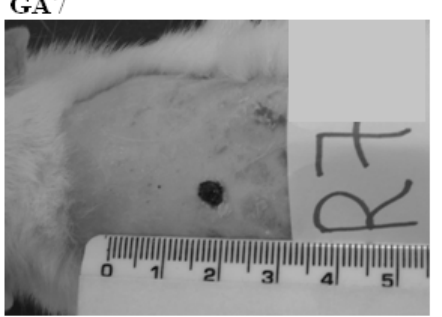

GA14

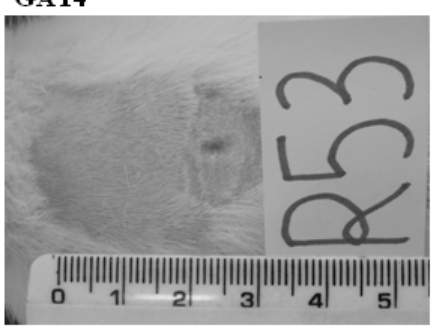

GB3

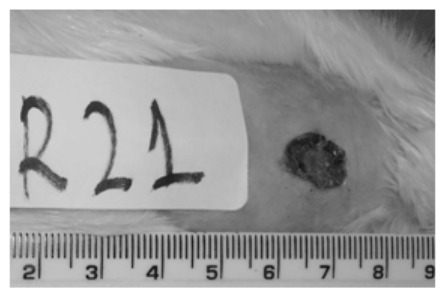

GB 7

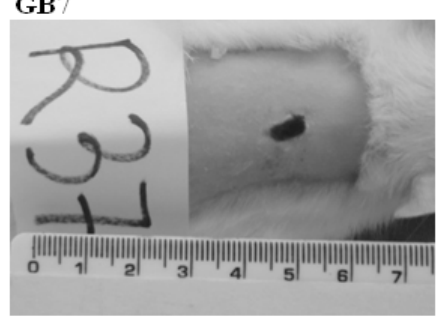

GB14

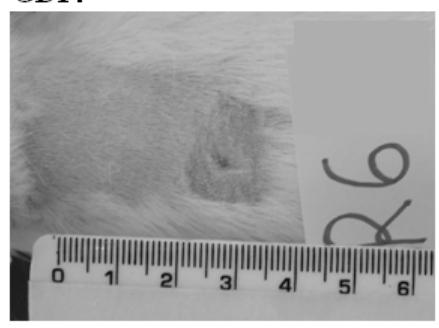

GS3

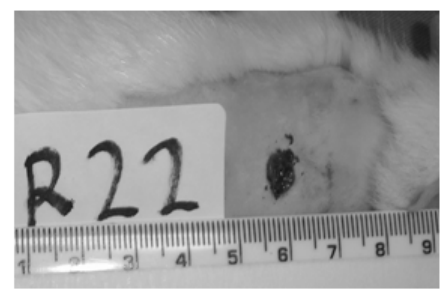

GS7

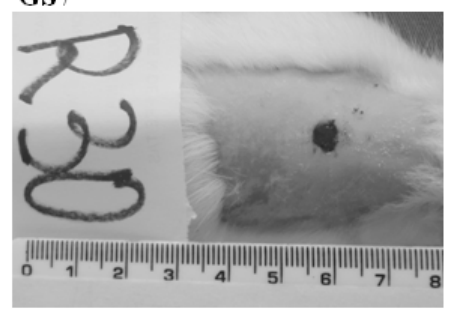

GS14

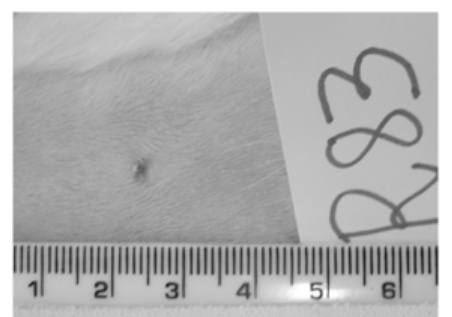

Figure 3 - Wound contraction in the HG, LG and SG at 3, 7 and 14 PO days.

Note: HG- High Frequency Group. LG $=$ Low Frequency Group. SG $=$ Simulated Group. PO = Postoperative.

\section{Discussion}

This is the first experimental study to evaluate the effect of high and low frequency TENS on angiogenesis and contraction of the acute excisional wound in rat skin through microscopic analysis with Hematoxylin Eosin (HE) and photographic evaluation.

Regarding the angiogenesis, there was an increase in the amount of blood vessels in the HG when compared to the LG and SG, at 3 PO days; and in the LG in relation to the $\mathrm{HG}$ and $\mathrm{SG}$, at $14 \mathrm{PO}$ days. Although the scientific basis is still insufficient, it is suggested that electrical stimulation (EE) releases Vascular Endothelial Growth Factor (VEGF), which may be responsible for the promotion of angiogenesis after the EE (33). After 14 days of EE in the skin of healthy humans, VEGF release showed significantly greater (66\%) expression when compared to the normal skin of humans who did not receive EE (24\%) (34).

Angiogenesis occurs at around the 5th to 7 th day after injury in the proliferative phase of the cicatrization process. Therefore, the increase in the amount of blood vessels observed in the HG (3 PO days) was influenced by the TENS, since this was stimulated early compared to the time of the physiological events of the cicatrization process. Another factor that reinforces the stimulation produced for the HG is that the SG did not present significant alteration in angiogenesis on the days evaluated (32). In the LG, angiogenesis was shown late considering the physiological events, because at 14 PO days it was expected that there would be no more significant changes, or that the SG would show more blood vessels. Therefore, the low frequency (LG) demonstrated a delay in angiogenesis according to the normal cicatrization process.

The findings of the present study differ from those of previous studies. Khalil \& Merhi (10), Kutlu et al. (13) and Gürgen et al. (23), obtained satisfactory results in wound healing using low frequency TENS ( 2 and $5 \mathrm{~Hz}$ ) for 5 consecutive days. The low frequency $(2 \mathrm{~Hz})$ stimulates healing by increasing levels of Epidermal Growth Factor (EGF) and PlateletDerived Growth Factor (PDGF) (32). After 45 minutes 
of TENS application, the increase in blood flow has been shown to be greater with low frequency (24\%) than with high frequency (17\%) (8).

Conversely, the use of high-frequency TENS has been proposed to improve blood flow in random skin flaps $(12,25,26)$. The $80 \mathrm{~Hz}$ value for $\mathrm{HG}$ was determined based on Abram et al. (5), and from random skin flap studies (70 to $100 \mathrm{~Hz})(12,25,26)$. In this range, there is evidence of increased skin temperature of about $+2.5^{\circ} \mathrm{C}$ and viability of the skin flap. For the $\mathrm{LG}$, the value of $5 \mathrm{~Hz}$ was established due to the effective local vascular improvement in the response of efferent sensory nerves in elderly rats and due to the findings of CGRP release $(10,11)$. It is believed that the time of application and the number of sessions proposed in the present study may have been insufficient for low frequency TENS to demonstrate positive effects.

Although the photographic evaluation presented better accuracy than measuring with a ruler or pachymeter or tracing on transparent film paper (35), and the photographic records were made following a specific standardization (31), no significant changes were demonstrated in the HG, LG and SG groups on the different $\mathrm{PO}$ days with regard to the percentage of wound contraction. It is suggested that the area an $8 \mathrm{~mm}$ wound is too small to determine macroscopic differences in healing and to compare the different groups (HG, LG and SG). Thus, the size of the wound may not have provided sensitivity to demonstrate the actual changes. The macroscopic analysis to verify the effect of the TENS on wound healing has already demonstrated satisfactory results in diabetic wounds $(6,15)$, leprosy wounds $(16)$, pressure ulcers $(17$, $18)$, burn injuries (10) and chronic venous ulcers $(19-21)$, which are wounds that have total areas greater than $8 \mathrm{~mm}$.

During the execution of the therapeutic procedure, a great stimulation of the animal was observed, according to the progressive increase of the amplitude of the current, which was responsible for generating continuous contractions in the dorsal region that altered minimally the positioning of the mouse on the surgical board. It is important to note that the amplitude of the current and size of the electrodes influence the current density $(d=I / a)$, which determines the physiological and therapeutic effects of the electrical stimulation (36). Khalil \& Merhi (10) used carbon electrodes measuring $1.5 \mathrm{~cm}^{2}$, but did not describe the amplitude of the current used, making it impossible to determine the density. Atalay \& Yilmaz (12) proposed the use of electrodes measuring $16 \mathrm{~cm}^{2}$ and, according to the current amplitude, the current density was $1.25 \mathrm{~mA} / \mathrm{cm}^{2}$. It is considered important to include information about the size of the electrodes used, as well as the mean amplitude reached, to favor the determination of the current density for the design of new studies.

It is suggested that there may be a need for small adjustments in the parameters stipulated for the application of the TENS to obtain satisfactory results. Acute wounds are considered to progress naturally through the cellular events that occur in the cicatrization stages (37). However, it is considered important to carry out studies with a similar design, including detailed information on the parameters used, to prove the effects of the different frequencies of TENS on wound cicatrization.

\section{Conclusion}

It was concluded that high frequency Transcutaneous Electrical Nerve Stimulation (TENS) stimulated angiogenesis and that neither frequency influenced the contraction of the acute excisional wound in rat skin.

\section{References}

1. Buonocore M, Camuzzini N. Increase of the threshold during and after high-frequency transcutaneous peripheral nerve stimulation in a group of normal subjects. Eura Medicophys. 2007;43(2):155-60.

2. Chen C, Johnson MI. A comparison of transcutaneous electrical nerve stimulation (TENS) at 3 and 80 pulses per second on cold-pressor pain in healthy human participants. Clin Physiol Funct Imaging. 2010;30(4):260-8.

3. Johnson MI, Paley CA, Howe TE, Sluka KA. Transcutaneous electrical nerve stimulation for acute pain. Cochrane Database Syst Rev. 2015;15(6):CD006142.

4. Nnoaham KE, Kumbang J. Transcutaneous electrical nerve stimulation (TENS) for chronic pain. Cochrane Database Syst Rev. 2014;10(7):CD003222.

5. Abram SE, Asiddao CB, Reynolds AC. Increased skin temperature during transcutaneous electrical stimulation. Anesth Analg. 1980;59(1):22-5. 
6. Debreceni L, Gyulai M, Debreceni A, Szabó K. Results of transcutaneous electrical stimulation (TES) in cure of lower extremity arterial disease. Angiology. 1995;46(7):613-8.

7. Forst T, Pfützner A, Bauersachs R, Arin M, Bach B, Biehlmaier $\mathrm{H}$, et al. Comparison of the microvascular response to transcutaneous electrical nerve stimulation and postocclusive ischemia in the diabetic foot. J Diabetes Complications. 1997;11(5):291-7.

8. Wikström OS, Svedman P, Henry S, Tanweer AS. Effect of transcutaneous nerve stimulation on microcirculation in intact skin and blister wounds in healthy volunteers. Scand J Plast Reconstr Surg Hand Surg, 1999;33(2):195-201.

9. Cosmo P, Svensson H, Bornmyr S, Wikström S. Effects of transcutaneous nerve stimulation on the microcirculation in chronic leg ulcers. Scand J Plast Reconstr Surg Hand Surg. 2000;34(1):61-4.

10. Khalil Z, Merhi M. Effects of aging on neurogenic vasodilator responses evoked by transcutaneous electrical nerve stimulation: relevance to wound healing. J Gerontol A Biol Sci Med Sci. 2000;55(6):B257-63.

11. Khalil Z, Merhi M, Livett BG. Differential involvement of conotoxin-sensitive mechanisms in neurogenic vasodilatation responses: effects of age. J Gerontol A Biol Sci Med Sci. 2001;56(8):B356-63.

12. Atalay C, Yilmaz KB. The effect of transcutaneous electrical nerve stimulation on postmastectomy skin flap necrosis. Breast Cancer Res Treat. 2009;117(3):611-4.

13. Kutlu AK, Çeçen D, Gürgen SG, SayJn O, Çetin F. A comparison study of growth factor expression following treatment with Transcutaneous Electrical Nerve Stimulation, saline solution, povidone-iodine, and lavender oil in wounds healing. Evid Based Complement Alternat Med. 2013;2013:361832.

14. Machado AFP, Santana EF, Tacani PM, Liebano RE. The effects os transcutaneous electrical nerve stimulation on tissue repair: a literature review. Can J Plast Surg. 2012;20(4):237-40.

15. Baker LL, Chambers R, Demuth SK, Villar F. Effects of electrical stimulation on wound healing in patients with diabetic ulcers. Diabetes Care. 1997;20(3):405-12.

16. Kaada B, Emru M. Promoted healing of leprous ulcers by transcutaneous nerve stimulation. Acupunct Electrother Res. 1988;13(4):165-76.
17. Karba R, Benko H, Savrin R, Vodovnik L. Combination of occlusive dressings and electrical stimulation in pressure ulcer treatment. Med Sci Res. 1995;23:671-3.

18. Baker LL, Rubayi S, Villar F, Demuth SK. Effect of electrical stimulation waveform on healing of ulcers in human beings with spinal cord injury. Wound Repair Regen. 1996;4(1):21-8.

19. Ogrin R, Darzins P, Khalil Z. Use of the sensory nerve stimulator to accelerate healing of a venous leg ulcer with sensory nerve dysfunction: a case study. Int Wound J 2005;2(3):242-51.

20. Ogrin R, Darzins P, Khalil Z. The use of sensory nerve stimulation and compression bandaging to improve sensory nerve function and healing of chronic venous leg ulcers. Curr Aging Sci. 2009;2(1):72-80.

21. Finsen L, Persen L, Løvlien M, Veslegaard EK, Simensen $\mathrm{M}$, Gåsvann AK, et al. Transcutaneous Electrical Nerve Stimulation After Major Amputation. J Bone Joint Surg Br. 1988;70(1):109-12.

22. Yarboro DD, Smith R. Transcutaenous electrical nerve stimulation to manage a lower extremity wound complicated by peripheral arterial disease: a case report. Ostomy Wound Manage. 2014;60(7):40-5.

23. Gürgen SG, Sayın O, Cetin F, Tuç Yücel A. Transcutaneous electrical nerve stimulation (TENS) accelerates cutaneous wound healing and inhibits pro-inflammatory cytokines. Inflammation. 2014;37(3):775-84.

24. Liebano RE, Ferreira LM, Sabino Neto M. The effect of the transcutaneous electrical nerve stimulation on the viability of random skin flaps in rats. Can J Plast Surg, 2002;10:151-4.

25. Liebano RE, Abla LEF, Ferreira LM. Effect of high frequency transcutaneous electrical nerve stimulation on viability of random skin flap in rats. Acta Cir Bras. 2006;21(3):133-8.

26. Liebano RE, Abla LEF, Ferreira LM. Effect of lowfrequency transcutaneous electrical nerve stimulation (TENS) on the viability of ischemic skin flaps in the rat: an amplitude study. Wound Repair Regen. 2008;16(1):65-9.

27. Ansell DM, Holden KA, Hardman MJ. Animal models of wound repair: are they cutting it? Exp Dermatol. 2012;21(8):581-5. 
28. Valacchi G, Zanardi I, Sticozzi C, Bocci V, Travagli V. Emerging topics in cutaneous wound repair. Ann N Y Acad Sci. 2012;1259:136-44.

29. Li J, Chen J, Kirsner R. Pathophysiology of acute wound healing. Clin Dermatol. 2007;25(1):9-18.

30. Medrado ARAP, Pugliese LS, Reis SRA, Andrade ZA. Influence of low level laser therapy on wound healing and its biological action upon myofibroblasts. Lasers Surg Med. 2003;32(3):239-44.

31. Hochman B, Nahas FX, Ferreira LM. Fotografia aplicada na pesquisa clínico-cirúrgica. Acta Cir Bras. 2005;20(Suppl 2):19-25.

32. Kloth LC. Electrical stimulation for wound healing: a review of evidence from in vitro studies, animal experiments, and clinical trials. Int J Low Extrem Wounds. 2005;4(1):23-44.

33. Bae SH, Bae YC, Nam SB, Choi SJ. A skin fixation method for decreasing the influence of wound contraction on wound healing in a rat model. Arch Plast Surg. 2012;39(5):457-62.

33. Liebano RE, Machado AFP. Vascular Endothelial Growth Factor release following electrical stimulation in human subjects. Adv Wound Care (New Rochelle). 2014;3(2):98-103.
34. Sebastian A, Syed F, Perry D, Balamurugan V, Colthurst J, Chaudhry IH, et al. Acceleration of cutaneous healing by electrical stimulation: Degenerate electrical waveform down-regulates inflammation, up-regulates angiogenesis and advances remodeling in temporal punch biopsies in a human volunteer study. Wound Repair Regen. 2011;19(6):693-708.

35. Papazoglou ES, Zubkov L, Mao X, Neidrauer M, Rannou $\mathrm{N}$, Weingarten MS. Image analysis of chronic wounds for determining the surface area. Wound Repair Regen. 2010;18(4):349-58.

36. Starkey C. Agentes elétricos. In: Starkey C, ed. Recursos terapêuticos em fisioterapia. São Paulo: Editora Manole; 2001. p.176-276.

37. Agha R, Ogawa R, Pietramaggiori G, Orgill DP. A Review of the Role of Mechanical Forces in Cutaneous Wound Healing. J Surg Res. 2011;171(2):700-8.

Received in 12/26/2015

Recebido em 26/12/2015

Approved in 03/07/2017

Aprovado em 07/03/2017 